\title{
HUBUNGAN PENGETAHUAN IBU TENTANG GIZI DAN TUMBUH KEMBANG ANAK SERTA STIMULASI PSIKOSOSIAL DENGAN PERKEMBANGAN KOGNITIF ANAK USIA 2-5 TAHUN
}

\author{
Relation Between Mother's Knowledge on Nutrition and Child's Growth Development to \\ Psychosocial Stimulation and Cognitive Development of Children Aged 2-5 Years Old
}

Novera Dwi Rahmaulina ${ }^{1}$, Dwi Hastuti ${ }^{2}$

\begin{abstract}
Purpose of this research were (1) to identify family's and child's characteristics, (2) to identify mother's knowledge on nutrition and child's growth development, mother's access to information on nutrition and child growth development, psychosocial stimulation, and child's cognitive development, (3) to analyze relationship between family's characteristics and mother's knowledge on nutrition and growth development, (4) to analyze relationship of family's characteristics, mother knowledge, child's characteristics and psychosocial stimulation, (5) to analyze relationship between mother's knowledge, psychosocial stimulation and child's cognitive development. A cross sectional design was assigned for this research. Population of this research were children aged 2-5 years old that located at Sub capital East Bogor and Kedungbadak were selected by random proportional from 297 children's to 100 sample which consist of aged 2-3 years old (37 children), 3-4 years old (50 children), and 4-5 years old (33 children). A correlation test of Rank Spearman was applied to test the correlation among variables. Results showed that there were significant and positive relationship among three variables which were family's characteristics (family's income and mother's education) and mother's knowledge. Meanwhile, mother's and father's educational attainment and family's income had a positive and significant correlation with psychosocial stimulation.. The study also found that psychosocial stimulation and mother's knowledge had a significant and positive relationship with child's cognitive development.
\end{abstract}

\section{Keywords: mother knowledge, psychosocial stimulation, child's cognitive}

\section{PENDAHULUAN}

Pembangunan

nasional

mempunyai tujuan untuk melakukan peningkatan kualitas Sumber Daya Manusia (SDM) (Soetjiningsih 2000). Kualitas SDM sangat ditentukan oleh kualitas pertumbuhan dan perkembangan anak yang dikembangkan melalui pengasuhan oleh keluarga, terutama orang tua. Untuk menjadi manusia yang berkualitas, maka harus didukung oleh perkembangan kognitif yang baik.

Kognitif berhubungan dengan aktivitas intelektual yang disadari seperti berpikir, menjelaskan, membayangkan, mempelajari kata, dan menggunakan bahasa (Webster 1993, diacu dalam Hastuti 2006). Pertumbuhan dan perkembangan anak sebagian besar terbentuk dalam keluarga. Penelitian ini bertujuan untuk: (1) mengidentifikasi karakteristik keluarga, (2) mengidentifikasi pengetahuan ibu mengenai gizi dan tumbuh kembang anak, akses informasi ibu mengenai gizi dan tumbuh kembang anak, pemberian stimulasi psikososial, serta perkembangan kognitif anak, (3) menganalisis hubungan karakteristik keluarga dengan pengetahuan ibu tentang gizi dan tumbuh kembang anak, menganalisis hubungan karakteristik keluarga, anak, dan pengetahuan ibu tentang gizi dan tumbuh kembang anak dengan pemberian stimulasi psikososial, dan (5) menganalisis hubungan pengetahuan ibu tentang gizi dan tumbuh kembang anak serta 
stimulasi psikososial dengan perkembangan kognitif anak.

\section{METODE}

Disain, Tempat, dan Waktu

Disain penelitian ini adalah cross sectional study. Penelitian ini merupakan bagian dari penelitian Yuliati (2006) yang berjudul "Studi Perilaku Pembelian dan Konsumsi Susu untuk Anak Usia 2-5 Tahun dan Dampaknya terhadap Pertumbuhan dan Perkembangan". Penelitian dilakukan di dua kecamatan, yaitu Kecamatan Bogor Timur (Kelurahan Baranangsiang dan Sukasari) dan Kecamatan Tanah Sareal (Kelurahan Tanah Sareal dan Kedung Badak). Pemilihan lokasi dilakukan secara purposive dengan pertimbangan bahwa wilayah tersebut memiliki status ekonomi yang beragam, akses informasi yang baik karena berada di pusat Kota Bogor, dan memiliki jumlah balita yang banyak. Pengumpulan data dilakukan pada bulan September 2006 sampai Februari 2007.

\section{Penarikan Contoh}

Populasi penelitian adalah keluarga dengan anak 2-5 tahun yang berlokasi di dua kecamatan terpilih. Responden dari penelitian adalah ibu yang memiliki anak berusia 2-5 tahun yang tinggal di lokasi terpilih dan anak, sedangkan contoh penelitian ini adalah anak usia 2-5 tahun. Pemilihan anak usia 2-5 tahun dilakukan karena pada usia 2-5 tahun terjadi pertumbuhan dan perkembangan paling pesat dari seorang anak karena pada saat itu anak mulai beradaptasi dengan lingkungan sekitarnya. Penentuan contoh dilakukan secara acak sederhana, sehingga diperoleh 297 contoh. Dari jumlah tersebut kemudian dipilih secara acak proporsional berdasarkan umur sebanyak 100 contoh.

Jenis dan Cara Pengumpulan Data Data yang dikumpulkan meliputi data primer dan sekunder. Data primer diperoleh dengan pengamatan dan wawancara langsung dengan menggunakan alat bantu kuesioner yang meliputi;

1. Karakteristik keluarga untuk mengetahui besar keluarga, pendidikan orangtua, pendapatan perkapita keluarga, pengetahuan ibu mengenai gizi dan tumbuh kembang anak

2. Stimulasi psikososial diukur dengan menggunakan indikator Home Observation for Measurement of the Environment (HOME).

3. Perkembangan kognitif anak diukur dengan melakukan wawancara dan pengamatan pada contoh dengan menggunakan checklist perkembangan kognitif yang bersumber dari dan telah diuji coba oleh Hastuti dan Dwiriani (2006).

Data sekunder yang dapat menunjang data primer dikumpulkan dari dinas kesehatan Kota Bogor, Puskesmas, Kecamatan, Kelurahan, serta instansi lain yang terkait.

\section{Pengolahan dan Analisis Data}

Data diolah dengan
menggunakan statistik deskriptif melalui sebaran, rata-rata, standar deviasi dan statistik inferensial melalui uji korelasi Spearman. Pengolahan data dilakukan dengan menggunakan Microsoft Excel dan SPSS 13.0 for Windows.

\section{HASIL DAN PEMBAHASAN}

Karakteristik Keluarga

Besar keluarga dikelompokkan menjadi tiga kategori, yaitu kecil, sedang, dan besar. Berdasarkan hasil penelitian dapat diketahui lebih dari separuh contoh $(>67.6 \%)$ termasuk ke dalam kategori keluarga kecil. Ratarata jumlah anggota keluarga contoh adalah empat orang.

Hasil Penelitian menunjukkan bahwa persentase terbesar $(\geq 62.2 \%)$ pendapatan per kapita per bulan keluarga contoh adalah kurang dari Rp 500 000. Berdasarkan BPS (2001), rata-rata pendapatan per kapita per 
bulan Kota Bogor adalah Rp 148000. Hal ini dapat menunjukkan bahwa sebagian besar keluarga contoh termasuk ke dalam status ekonomi cukup karena memiliki rata-rata pendapatan per kapita perbulan sebesar Rp 564138.

Pendidikan orangtua dibagi menjadi empat tingkat, yaitu SD, SMP, SMU, dan Perguruan Tinggi. Berdasarkan hasil penelitian dapat diketahui lebih dari sepertiga ayah $(\geq 38.5 \%)$ dan ibu contoh ( $\geq 34.0 \%)$ memiliki pendidikan SMU. Rata-rata pendidikan orangtua contoh adalah SMU (10-12 tahun).

Karakteristik Anak

Umur anak dibagi menjadi tiga kelompok umur, yaitu 2-3 tahun, 3-4 tahun, dan 4-5 tahun. Berdasarkan hasil penelitian dapat diketahui persentase terbesar (50\%) umur anak terdapat pada kisaran umur 3-4 tahun. Sementara itu, persentase terbesar (55\%) untuk jenis kelamin anak adalah perempuan.

\section{Pengetahuan Ibu}

Pengetahuan ibu dibagi menjadi dua jenis pengetahuan, yaitu pengetahuan gizi dan tumbuh kembang anak. Pengetahuan ibu tentang gizi dan tumbuh kembang anak, dibagi menjadi tiga kategori, yaitu kurang $(<60 \%)$, sedang (60$80 \%)$, dan baik (>80\%) (Khomsan 2000). Pada tabel 1 dapat diketahui bahwa lebih dari separuh ibu contoh $(\geq 50 \%)$ memiliki pengetahuan tentang gizi dan tumbuh kembang anak yang termasuk ke dalam kategori sedang.

Tabel 1. Sebaran ibu contoh berdasarkan pengetahuan gizi dan tumbuh kembang anak

\begin{tabular}{|c|c|c|c|c|c|c|}
\hline \multirow{3}{*}{ Pengetahuan Ibu } & \multicolumn{6}{|c|}{ Umur (tahun) } \\
\hline & \multicolumn{2}{|c|}{$2-3$} & \multicolumn{2}{|c|}{$3-4$} & \multicolumn{2}{|c|}{$4-5$} \\
\hline & $\mathrm{n}$ & $\%$ & $\mathrm{n}$ & $\%$ & $\mathrm{n}$ & $\%$ \\
\hline Kurang & 11 & 29.7 & 17 & 34.0 & 4 & 30.8 \\
\hline Sedang & 24 & 64.9 & 32 & 64.0 & 9 & 69.2 \\
\hline Baik & 2 & 5.4 & 1 & 2.0 & 0 & 0.0 \\
\hline Total & 37 & 100 & 50 & 100 & 13 & 100 \\
\hline Rata-rata + SD & & & & 10.6 & & \\
\hline $\begin{array}{l}\text { Tumbuh; Kurang } \\
\text { Kembang }\end{array}$ & 6 & 16.2 & 7 & 14.0 & 1 & 7.7 \\
\hline Sedang & 19 & 51.4 & 18 & 36.0 & 7 & 53.8 \\
\hline Baik & 12 & 32.4 & 25 & 50.0 & 5 & 38.5 \\
\hline Total & 37 & 100 & 50 & 100 & 13 & 100 \\
\hline Rata-rata + SD & & & & 13.3 & & \\
\hline
\end{tabular}

Berdasarkan pengetahuan ibu tentang gizi, rata-rata 67.1 persen pertanyaan mengenai gizi dapat dijawab dengan benar oleh ibu contoh. Sebagian besar ibu contoh (>75\%) dapat menjawab dengan benar pertanyaan mengenai mengenai perbedaan antara kolustrum ASI dan susu formula, sumber DHA, fungsi kolustrum, kandungan gizi buah dan sayur, fungsi protein, prebiotik, dan kandungan mineral pada susu. Namun pengetahuan ibu tentang gizi yang umumnya kurang diketahui oleh ibu contoh adalah jenis pemberian MPASI dan tahap pemberian makan anak yang tepat, kandungan gizi pada susu skim, dan fungsi buah dan sayur bagi tubuh.

Berdasarkan pengetahuan ibu tentang tumbuh kembang anak, ratarata 80.4 persen pertanyaan mengenai tumbuh kembang anak dapat dijawab dengan benar oleh ibu contoh. Sebagian besar ibu contoh (>78\%) dapat menjawab dengan benar pertanyaan mengenai pentingnya mengajak anak berbicara sejak bayi, mendengarkan musik selama kehamilan, perkembangan otak anak 
batita yang berkembang cepat, perlunya anak batita untuk bersosialisasi dengan lingkungan, pentingnya pembagian peran pengasuhan antara ayah dan ibu, pentingnya bermain dan memberi kesempatan anak bertanya untuk merangsang kecerdasan anak. Namun pengetahuan ibu tentang tumbuh kembang anak yang umumnya kurang diketahui oleh ibu contoh adalah pentingnya mengajarkan anak untuk bermain bersama binatang.

Untuk memperoleh pengetahuan mengenai gizi, lebih dari separuh ibu contoh (>60\%) memperoleh dari dokter/bidan/kader dan TV. Sementara itu untuk mendapatkan pengetahuan mengenai tumbuh kembang anak, sebagian besar ibu contoh (88\%) memperoleh dari teman/keluarga.
Stimulasi Psikososial

Stimulasi psikososial dibagi menjadi dua kelompok umur, yaitu umur 2-3 tahun dan 3-5 tahun. Stimulasi psikososial pada anak umur 2-3 tahun dibagi menjadi 6 subskala, yaitu tanggap rasa dan kata, penerimaan terhadap perilaku anak, pengorganisasian lingkungan anak, penyediaan mainan untuk anak, keterlibatan ibu terhadap anak, dan kesempatan variasi asuhan anak. Pada Gambar 1 dapat dilihat bahwa pemberian stimulasi psikososial yang kurang pada anak usia 2-3 tahun adalah penerimaan terhadap perilaku anak dan penyediaan mainan untuk anak.

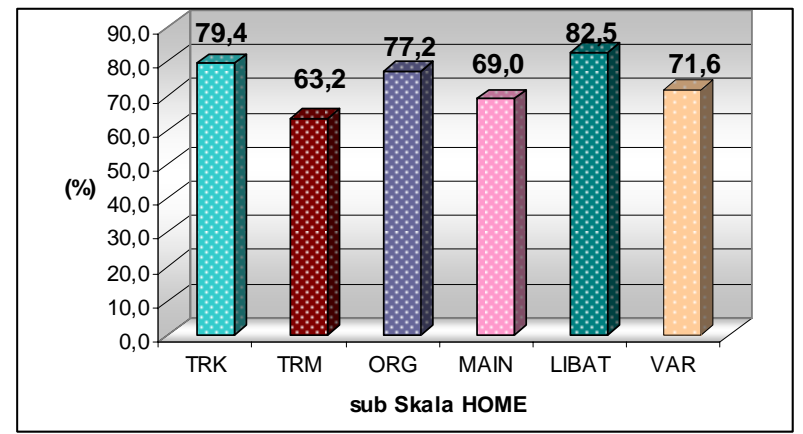

$$
\begin{aligned}
& \text { Keterangan: } \\
& \text { TRK : Tanggap Rasa dan kata } \\
& \text { TRM : Penerimaan thd } \\
& \text { Perilaku Anak } \\
& \text { ORG : Pengorganisasian } \\
& \text { Lingk.Anak } \\
& \text { MAIN : Penyediaan Mainan } \\
& \text { Anak } \\
& \text { LIBAT : Keterlibatan Ibu thd } \\
& \text { Anak } \\
& \text { VAR : Kesempatan Variasi } \\
& \text { Asuhan Anak }
\end{aligned}
$$

\section{Gambar 1. Rata-rata subskala HOME anak usia 2-3 tahun}

Stimulasi psikososial pada anak usia 3-5 tahun dibagi menjadi delapan subskala, yaitu stimulai belajar, stimulasi bahasa, lingkungan fisik, kehangatan dan penerimaan, stimulasi akademik, modeling, variasi stimulasi pada anak, dan hukuman. Pada gambar 2 dapat dilihat bahwa pemberian stimulasi psikososial yang kurang pada anak usia 3-5 tahun adalah stimulasi belajar dan modeling.

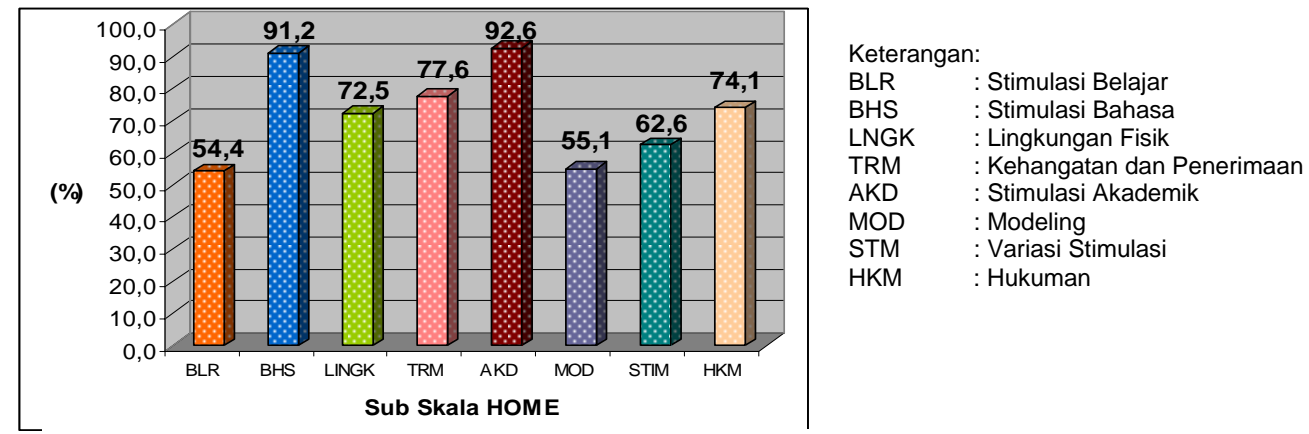

Gambar 2. Rata-rata subskala HOME anak usia 3-5 tahun 
Tabel 2.

Sebaran

berdasarkan

psikososial pada masingmasing kelompok umur

\begin{tabular}{|c|c|c|c|c|c|c|}
\hline \multirow{2}{*}{ Kategori } & \multicolumn{6}{|c|}{ Umur (tahun) } \\
\cline { 2 - 7 } & \multicolumn{2}{|c|}{$\mathbf{2 - 3}$} & \multicolumn{2}{|c|}{$\mathbf{3 - 4}$} & \multicolumn{2}{|c|}{$\mathbf{4 - 5}$} \\
\cline { 2 - 7 } & $\mathbf{n}$ & $\mathbf{\%}$ & $\mathbf{n}$ & $\mathbf{\%}$ & $\mathbf{n}$ & $\%$ \\
\hline Rendah & 3 & 8.1 & 1 & 2.0 & 0 & 0.0 \\
\hline Sedang & 2 & $\mathbf{6 7 . 6}$ & 4 & $\mathbf{8 8 . 0}$ & 1 & $\mathbf{7 6 . 9}$ \\
\hline Tinggi & 9 & 24.3 & 5 & 10.0 & 3 & 23.1 \\
\hline Total & 3 & 100 & 5 & 100 & 1 & 100 \\
\hline $\begin{array}{c}\text { Rata-rata } \\
\text { + SD }\end{array}$ & 7 & \multicolumn{3}{|c|}{$73.8 \pm 9.5$} & \multicolumn{5}{|c|}{$70.5 \pm 9.8$} \\
\hline
\end{tabular}

Berdasarkan tabel 2 dapat diketahui bahwa lebih dari separuh contoh $(\geq 67.6 \%)$ menerima stimulasi psikososial yang termasuk ke dalam kategori sedang (56.2-80.9\%). Bila anak mendapatkan stimulasi, bila ia diterima, bila ia memperoleh kehangatan, maka hal-hal ini akan berpengaruh sangat positif bagi perkembangan yang sehat.

\section{Perkembangan Kognitif}

Pengukuran perkembangan kognitif dibagi menjadi tiga kelompok umur, yaitu 2-3 tahun, 3-4 tahun, dan 4-5 tahun. Berdasarkan Tabel 3 dapat diketahui bahwa sebagian besar contoh (>80\%) termasuk ke dalam kategori baik.

Tabel 3. Sebaran contoh berdasarkan perkembangan kognitif pada masing-masing kelompok umur

\begin{tabular}{|c|c|c|c|c|c|c|c|c|}
\hline \multirow{3}{*}{$\begin{array}{c}\text { Kategori } \\
\text { Perkembangan } \\
\text { Kognitif }\end{array}$} & \multicolumn{6}{|c|}{ Umur (tahun) } & \multirow{2}{*}{\multicolumn{2}{|c|}{ Total }} \\
\hline & \multicolumn{2}{|c|}{$2-3$} & \multicolumn{2}{|c|}{ 3-4 } & \multicolumn{2}{|c|}{$4-5$} & & \\
\hline & $\mathbf{n}$ & $\%$ & $\mathbf{n}$ & $\%$ & $\mathbf{n}$ & $\%$ & $\mathbf{n}$ & $\%$ \\
\hline Kurang & 1 & 2.7 & 0 & 0.0 & 0 & 0.0 & 1 & 1.0 \\
\hline Sedang & 3 & 8.1 & 8 & 16.0 & 2 & 15.4 & 13 & 13.0 \\
\hline Baik & 33 & 89.2 & 42 & 84.0 & 11 & 84.6 & 86 & 86.0 \\
\hline Total & 37 & 100 & 50 & 100 & 13 & 100 & 100 & 100 \\
\hline
\end{tabular}

Hubungan Karakteristik Keluarga dengan Pengetahuan.

Pendapatan Keluarga. Pada Gambar 3 dapat dilihat bahwa pengetahuan ibu mengenai gizi dan tumbuh kembang anak tertinggi terdapat pada keluarga contoh yang pendapatan perkapita perbulannya lebih dari Rp 2000 000. Semakin tinggi pendapatan perkapita keluarga, maka pengetahuan ibu mengenai gizi dan tumbuh kembang semakin baik. Hasil uji korelasi menunjukkan bahwa pendapatan perkapita perbulan berhubungan sangat nyata dengan pengetahuan ibu mengenai gizi dan tumbuh kembang anak $(p<0.01, r$ $=0.285$ ).

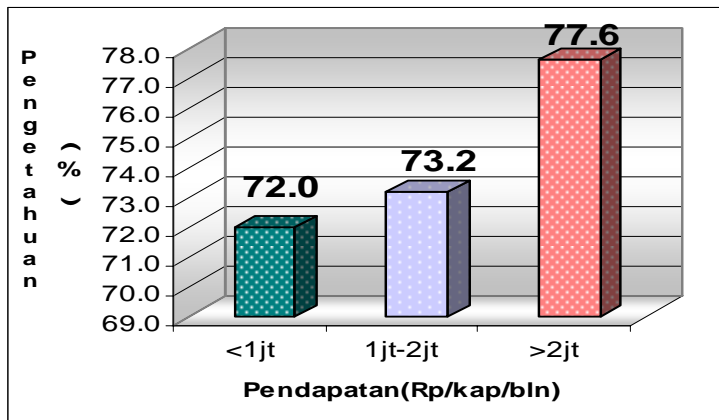

Gambar 3. Sebaran contoh berdasarkan pendapatan keluarga dan pengetahuan ibu 
Pendidikan Ibu. Pada gambar 4 dapat dilihat bahwa pengetahuan ibu mengenai gizi dan tumbuh kembang anak tertinggi terdapat pada keluarga contoh yang pendidikan terakhir ibunya adalah Perguruan Tinggi. Semakin tinggi pendidikan ibu, maka semakin baik pula pengetahuan ibu mengenai gizi dan tumbuh kembang. Hasil uji korelasi menunjukkan adanya hubungan yang sangat nyata antara pengetahuan ibu dengan pendidikan ibu $(p<0.01, r=0.299)$

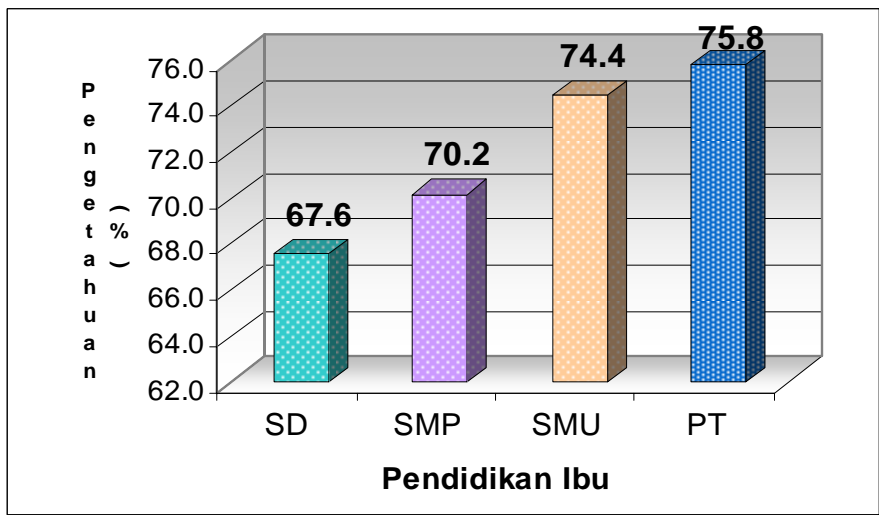

Gambar 4. Sebaran contoh berdasarkan pendidikan ibu dan pengetahuan ibu

Hubungan Karakteristik Keluarga dan Anak Dengan Stimulasi Psikososial.

Besar Keluarga. Pada gambar 5 dapat dilihat bahwa stimulasi psikososial tertinggi terdapat pada contoh yang memiliki ukuran keluarga kecil. Hasil uji korelasi menunjukkan tidak adanya hubungan yang nyata antara stimulasi psikososial dengan besar keluarga contoh.

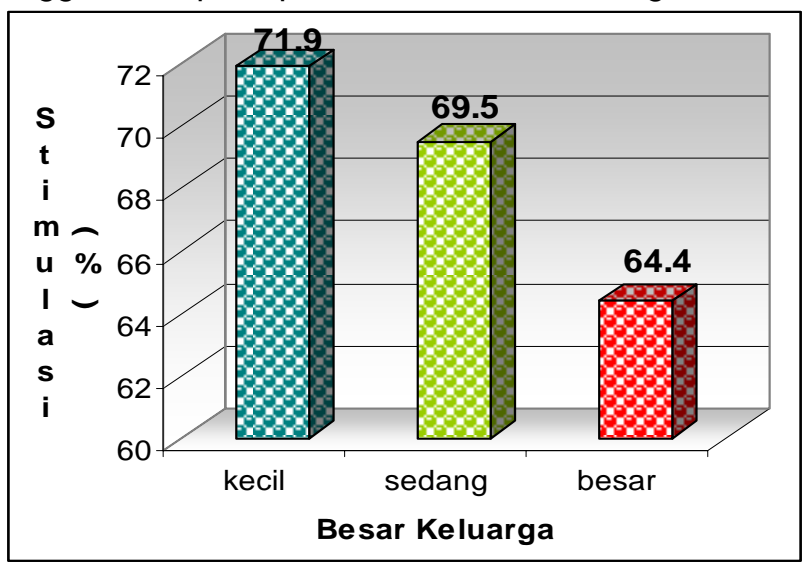

Gambar 5 . Sebaran contoh berdasarkan besar keluarga dan stimulasi psikososial

Pendapatan Keluarga. Pada gambar 6 dapat dilihat bahwa pemberian stimulasi psikososial tertinggi terdapat pada keluarga contoh yang memiliki pendapatan perkapita lebih dari $2000 \quad 000$ perbulan. Semakin besar pendapatan perkapita, maka pemberian stimulasi psikososial semakin tinggi. Uji korelasi menunjukkan adanya hubungan yang sangat nyata antara pendapatan perkapita dengan stimulasi psikososial $(p<0.01, r=0.422)$. 


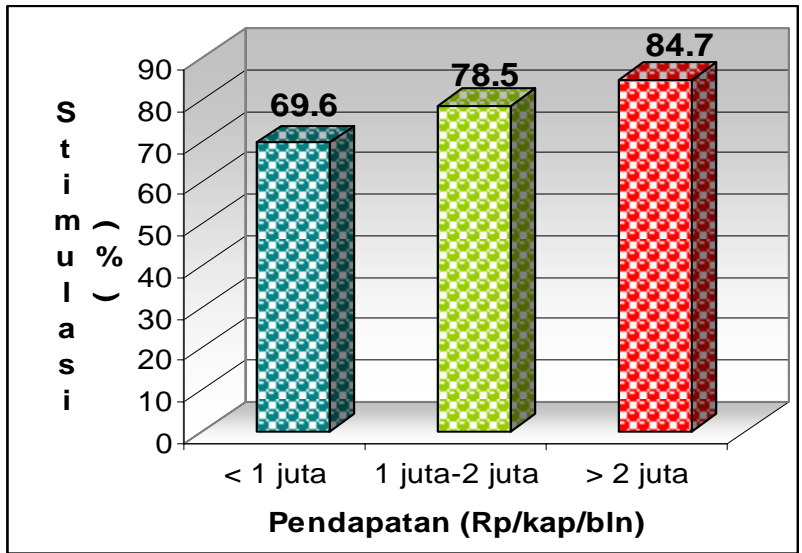

Gambar 6 . Sebaran contoh berdasarkan pendapatan keluarga dan stimulasi psikososial

Pendidikan Orangtua. Pada pemberian stimulasi psikososial gambar 7 dapat dilihat bahwa semakin tinggi. Uji korelasi pemberian stimulasi psikososial menunjukkan adanya hubungan yang tertinggi terdapat pada contoh yang sangat nyata antara pendidikan ayah memiliki ayah dengan pendidikan dengan stimulasi psikososial $(p<0.01$, perguruan tinggi. Semakin tinggi $r=0.365$ ).

tingkat pendidikan ayah, maka

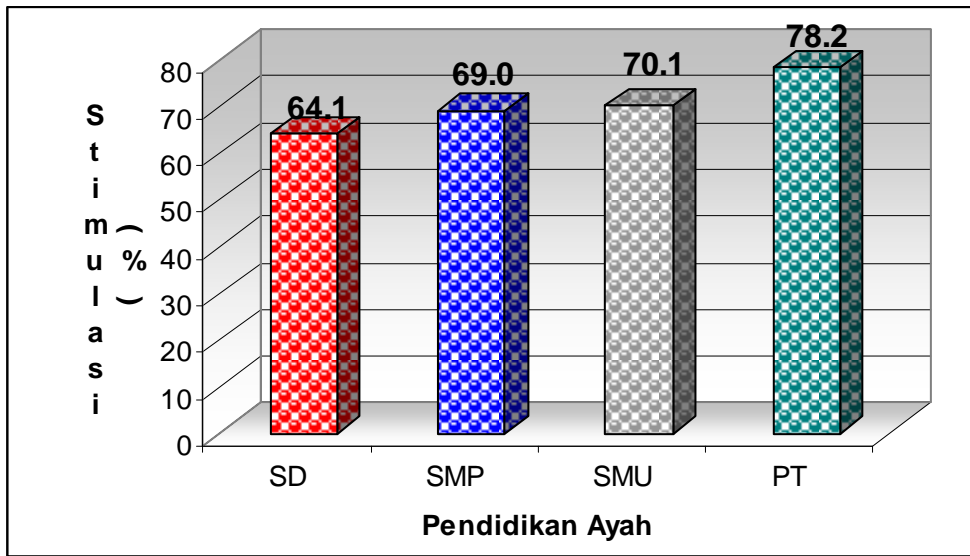

Gambar 7. Sebaran contoh berdasarkan pendidikan ayah dan stimulasi psikososial

Pada gambar 8 dapat dilihat bahwa pemberian stimulasi psikososial tertinggi terdapat pada contoh yang memiliki ibu dengan pendidikan perguruan tinggi. Semakin tinggi tingkat pendidikan ibu, maka pemberian stimulasi psikososial kepada anak semakin tinggi. Uji korelasi menunjukkan adanya hubungan yang sangat nyata antara pendidikan ibu dengan stimulasi psikososial $(p<0.01, r=0.361)$. 


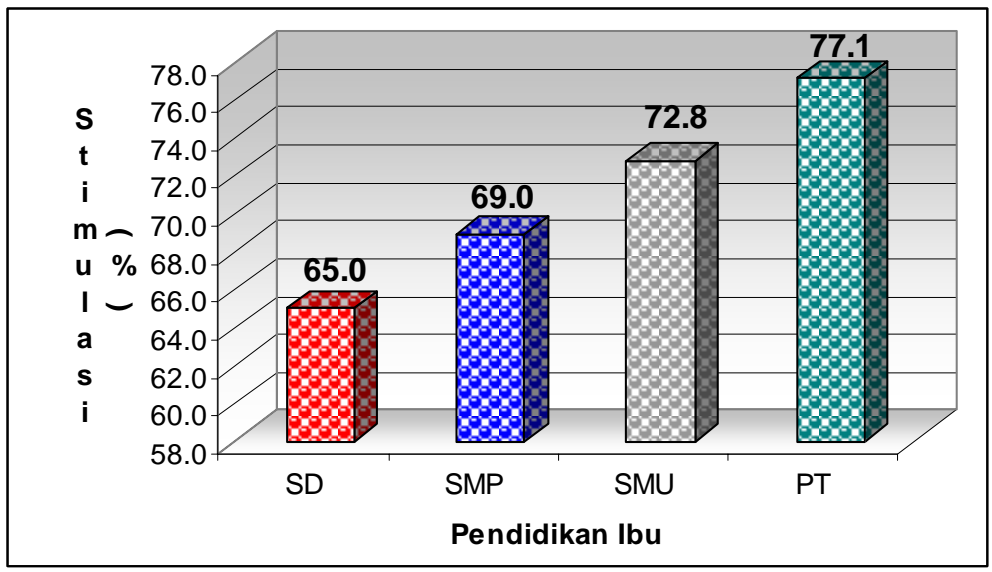

Gambar 8 . Sebaran contoh berdasarkan pendidikan ibu dan stimulasi psikososial

Pengetahuan Ibu. Pada gambar 9 dapat dilihat bahwa pemberian stimulasi psikososial tertinggi terdapat pada contoh yang memiliki ibu dengan pengetahuan gizi dan tumbuh kembang yang baik. Hasil uji korelasi menunjukkan tidak ada hubungan yang nyata antara pengetahuan ibu dengan stimulasi psikososial

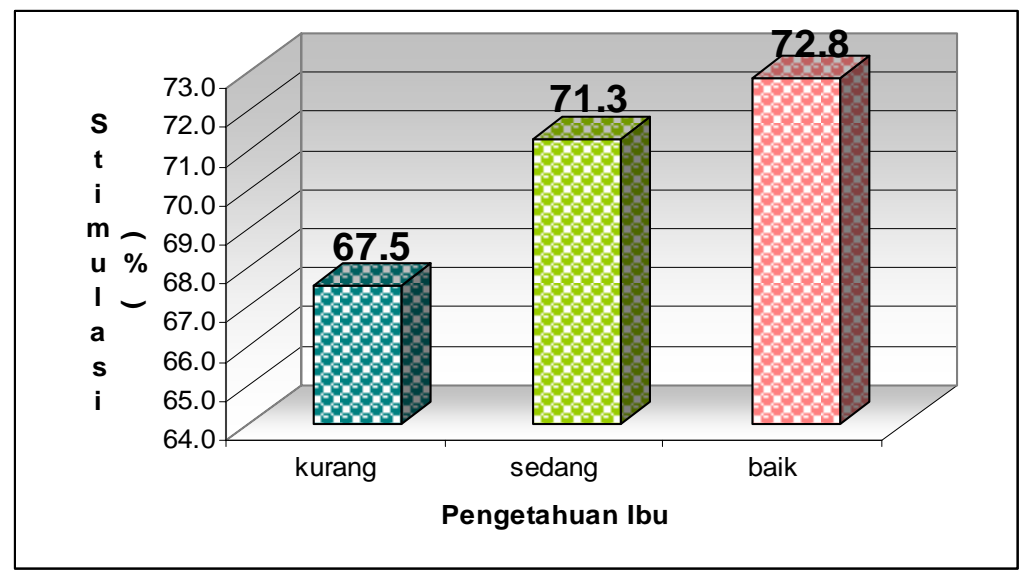

Gambar 9 Sebaran contoh berdasarkan pengetahuan ibu dan stimulasi psikososial

Jenis Kelamin. Pada gambar 10 dapat dilihat bahwa contoh perempuan memiliki rata-rata stimulasi psikososial yang lebih baik dibandingkan dengan laki-laki. Uji korelasi menunjukkan tidak adanya hubungan yang nyata antara jenis kelamin dengan stimulasi psikososial. 


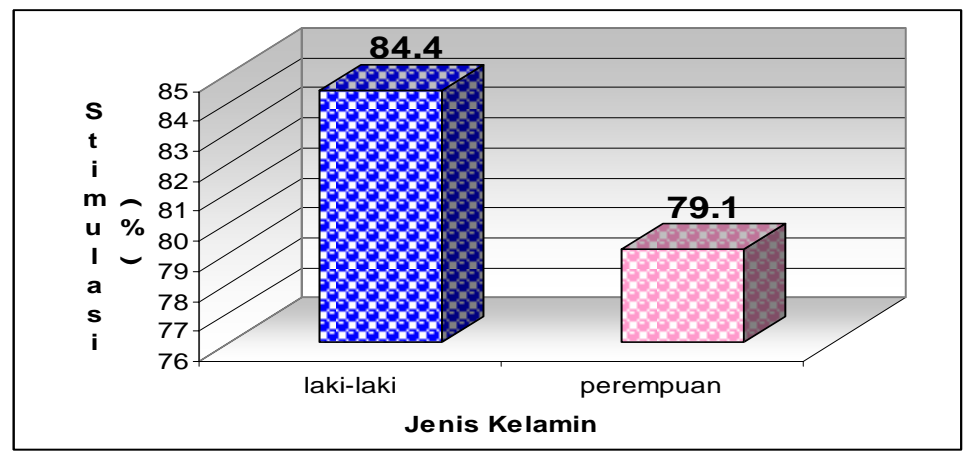

Gambar 10. Sebaran contoh berdasarkan jenis kelamin dan stimulasi psikososial

Umur Anak. Pada gambar 11 dapat dilihat bahwa stimulasi psikososial tertinggi terdapat pada contoh yang berumur 2-3 tahun. Uji korelasi tidak menunjukkan adanya hubungan yang nyata antara umur contoh dengan pemberian stimulasi psikososial

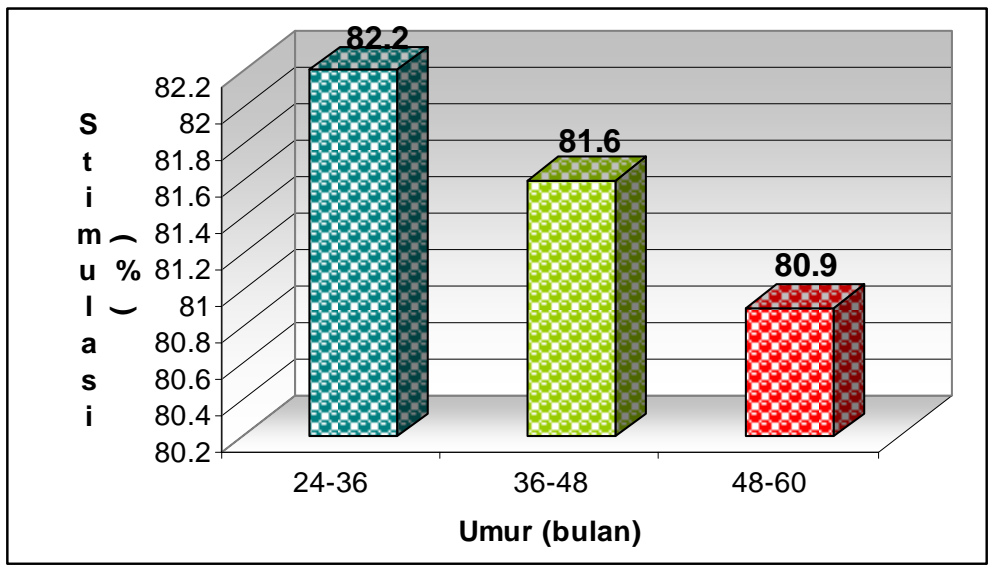

Gambar 11 Sebaran contoh berdasarkan umur anak dan stimulasi psikososial

Hubungan Pengetahuan lbu Dan Stimulasi Psikososial Dengan Perkembangan Kognitif.

Pengetahuan Ibu. Pada gambar 12 dapat dilihat bahwa perkembangan kognitif anak tertinggi terdapat pada ibu yang pengetahuan mengenai gizi dan tumbuh kembangnya termasuk dalam kategori baik. Semakin baik pengetahuan ibu mengenai gizi dan tumbuh kembang, maka semakin baik pula perkembangan kognitif anak. Uji korelasi menyatakan adanya hubungan yang nyata antara pengetahuan ibu mengenai gizi dan tumbuh kembang dengan perkembangan kognitif anak $(p<0.05, r$ $=0.244)$. 


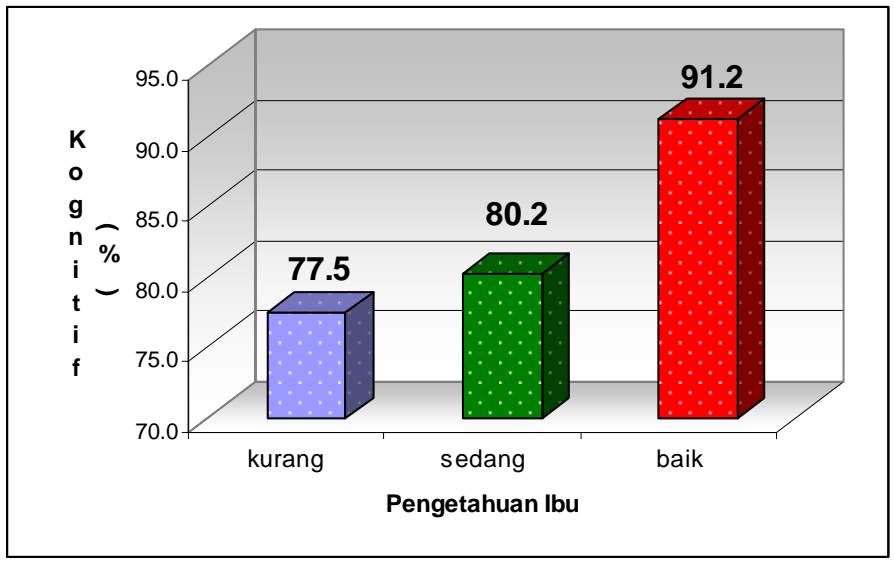

Gambar 12 . Sebaran contoh berdasarkan pengetahuan ibu dan perkembangan kognitif

Stimulasi Psikososial. Pada gambar 13 dapat dilihat bahwa perkembangan kognitif contoh tertinggi terdapat pada contoh yang diberikan stimulasi psikososial yang tinggi. Semakin tinggi stimulasi psikososial, maka perkembangan kognitif contoh berjalan semakin baik. Uji korelasi menunjukkan adanya hubungan yang sangat nyata antara stimulasi psikososial dengan perkembangan kognitif contoh $(p<0.01, r=0.249)$.

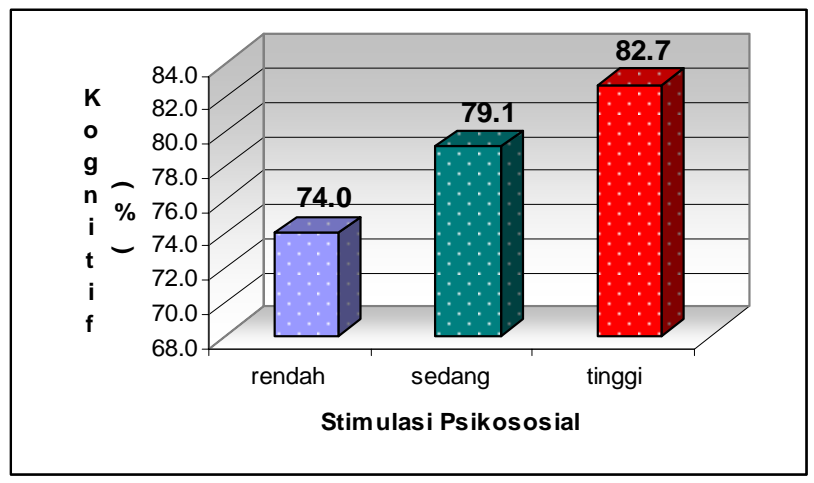

Gambar 13. Sebaran contoh berdasarkan stimulasi psikososial dan perkembangan kognitif

\section{SIMPULAN DAN SARAN}

Simpulan

Hasil penelitian ini menunjukkan adanya hubungan yang nyata dan positif dengan pengetahuan ibu mengenai gizi dan tumbuh kembang anak serta pemberian stimulasi psikososial pada anak sehingga dengan semakin tinggi pendapatan perkapita dan pendidikan orangtua maka pengetahuan ibu mengenai gizi dan tumbuh kembang anak serta pemberian stimulasi psikososial semakin baik. Pengetahuan ibu mengenai gizi dan tumbuh kembang anak serta stimulasi psikososial juga menunjukkan hubungan yang positif dan signifikan dengan perkembangan kognitif anak. Semakin tinggi pengetahuan ibu mengenai gizi dan tumbuh kembang anak, serta pemberian stimulasi psikososial pada anak maka perkembangan kognitif anak semakin baik pula.

\section{$\underline{\text { Saran }}$}

Peningkatan pengetahuan ibu mengenai gizi dan tumbuh kembang 
anak, diperlukan adanya peran dan keterlibatan program dari Dinas Pendidikan, Dinas Kesehatan (Puskesmas), LSM, Perguruan tinggi yang dibantu oleh kader Posyandu untuk dapat mensosialisasikan pengetahuan yang berkaitan dengan gizi dan tumbuh kembang anak, dengan melakukan penyuluhan terpadu mengenai tahapan dalam pemberian makan anak, fungsi zat gizi bagi tubuh, dan pentingnya mengajak anak bermain, serta stimulasi belajar yang diperlukan oleh anak usia 3-5 tahun.

\section{DAFTAR PUSTAKA}

Anwar F. 2002. Model Pengasuhan Anak Bawah Dua Tahun dalam Meningkatkan Status Gizi dan Perkembangan Sosial [disertasi]. Bogor: Program Pascasarjana, Institut Pertanian Bogor.

Baraja A. 2005. Psikologi Perkembangan, Tahapan-Tahapan, dan Aspek-Aspeknya (dari 0 tahun hingga akhil baliq). Jakarta: Studia Press.

Desmita. 2005. Psikologi Perkembangan. Bandung: PT Remaja Rosdakarya.

Engle PL, Menon P, Haddad L. 1997. Care and Nutrition: Concepts and Measurement Washington $\mathrm{D} \quad \mathrm{C}$ : International Food Policy research Institute.

Gunarsa SD \& Gunarsa YSD. 2000. Psikologi Perkembangan Anak: Anak, Remaja, dan Keluarga. Jakarta: PT BPK Gunung Mulia.

\footnotetext{
------------. 2006. Dasar dan Teori Perkembangan Anak. Jakarta : PT BPK Gunung Mulia

Hastuti D. 2006. Analisis Pengaruh Model Pendidikan Prasekolah pada Pembentukan Anak Sehat, Cerdas dan Berkarakter [disertasi]. Bogor: Program Pascasarjana, Institut Pertanian Bogor.

Hastuti D.\& Dwirian C.M. 2006. Analisis Stimulasi Gizi dan Stimulasi Psikososial di Taman Bermain Anak dan Pengaruhnya Pada Tumbuh Kembang Anak. Departemen IImu Keluarga dan Konsumen, FEMA-IPB.
}

Hawadi RA. 2001. Psikologi Perkembangan Anak. Jakarta: Gramedia Widiasarana Indonesia.

Monks FJ, AMP Knoers, \& SR Haditono. 2002. Psikologi Perkembangan. Yogyakarta: UGM Press

Munandar SCU. 1985. Emansipasi dan Peran Ganda Wanita Indonesia. Jakarta: UI Press.
Olson WC. 1949. Child Development. Boston : Health and Company.

Soetjiningsih. 1995. Tumbuh Kembang Anak. Jakarta: EGC

---. 2000. Kalender Tumbuh Kembang Balita Pendekatan Baru Deteksi Dini Penyimpangan Tumbuh Kembang Balita oleh Keluarga. Jakarta: Puslitbang (PULIK)-BKKBN

Yuliana. 2004. Pengaruh Gizi, Pengasuhan, dan Lingkungan terhadap Pertumbuhan dan Perkembangan Anak Usia Prasekolah. Bogor: IPB Press.

1 Departemen Gizi Masyarakat dan Sumberdaya Keluarga, IPB

2 Departemen Ilmu Keluarga dan Konsumen, IPB

Alamat Korespondensi: Herien Puspitawati Departemen IImu Keluarga dan Konsumen, Fakultas Ekologi Manusia IPB Jl. Lingkar Kampus IPB Darmaga 16680 Telp. (0251) 8628303, Fax. (0251) 8627432 